\title{
Effect of Crossbreeding on Beef Production of Jersey Herd Using Fleckvieh Sires Maintained on a Pasture-Based Feeding System
}

\author{
Sindisile Goni1,2*, Carel Johan Christiaan Muller³, Bekezela Dube ${ }^{2,4}$, Kennedy Dzama² \\ ${ }^{1}$ Döhne Agricultural Development Institute, Stutterheim, South Africa \\ ${ }^{2}$ Department of Animal Sciences, University of Stellenbosch, Stellenbosch, South Africa \\ ${ }^{3}$ Western Cape Department of Agriculture, Research and Technology Development Services, Directorate: \\ Animal Sciences, Elsenburg, South Africa \\ ${ }^{4}$ Agricultural Research Council, Irene, South Africa \\ Email: "Sindisile.goni@drdar.gov.za
}

Received 22 January 2016; accepted 21 June 2016; published 24 June 2016

Copyright (C) 2016 by authors and Scientific Research Publishing Inc.

This work is licensed under the Creative Commons Attribution International License (CC BY).

http://creativecommons.org/licenses/by/4.0/

(c) (i) Open Access

\section{Abstract}

Jersey bull calves and steers produce high quality meat; however, the growth rate of Jersey bull calves for veal and beef are low in comparison to other dairy breeds. This could be improved by crossbreeding with beef breeds. In the current study, the veal and beef production of Jersey and Fleckvieh $\times$ Jersey $(\mathrm{F} \times \mathrm{J})$ bull calves and steers were compared. Bull calves were reared intensively for veal up to a carcass weight not exceeding $100 \mathrm{~kg}$, or as steers for beef to 21 months of age. In both veal and steer production systems, the mean birth weight of $\mathrm{F} \times \mathrm{J}$ bull calves was higher $(\mathrm{P}<$ $0.001)$ than Jersey bull calves, i.e. $33.5 \pm 1.2 \mathrm{~kg}$ vs. $27.9 \pm 1.2 \mathrm{~kg}$ and $(33.4 \pm 0.9 \mathrm{~kg}$ vs. $26.9 \pm 0.9 \mathrm{~kg}$, respectively. The body weight of Jersey and $F \times J$ veal calves at 6 months of age differed $(P<0.01)$ being $163.5 \pm 3.9$ and $180.6 \pm 4.0 \mathrm{~kg}$ respectively. This could be attributed to a higher $(P<0.01)$ average daily gain (ADG) of $0.82 \pm 0.02 \mathrm{~kg} /$ day for $F \times J$ compared to $0.73 \pm 0.02 \mathrm{~kg} /$ day for Jersey bull calves. Marketing age in the veal production system differed $(P<0.001)$ with Jersey and $F \times J$ bull calves marketed at $7.1 \pm 0.1$ and $6.3 \pm 0.1$ months of age, respectively. End live weight at 21 months of age of Jersey and $F \times J$ differed $(P<0.01)$ being $322.6 \pm 13.4$ and $441.4 \pm 14.9 \mathrm{~kg}$ respectively. This was due to a higher $(\mathrm{P}<0.01)$ average daily gain in $\mathrm{F} \times \mathrm{J}$ vs. Jersey steers, i.e. $0.64 \pm$ 0.02 and $0.46 \pm 0.0 \mathrm{~kg} /$ day, respectively. Fleckvieh $\times$ Jersey steers had a higher $(P<0.01)$ carcass weight at 21 months of age being $206.5 \pm 8.9 \mathrm{~kg}$ vs. $157.9 \pm 8.6 \mathrm{~kg}$ respectively. These results indicated the potential of improving beef production characteristics of the Jersey cattle through cros-

${ }^{*}$ Corresponding author.

How to cite this paper: Goni, S., Muller, C.J.C., Dube, B. and Dzama, K. (2016) Effect of Crossbreeding on Beef Production of Jersey Herd Using Fleckvieh Sires Maintained on a Pasture-Based Feeding System. Open Journal of Animal Sciences, 6, 163168. http://dx.doi.org/10.4236/ojas.2016.63021 


\section{sbreeding.}

Keywords

Average Daily Gain, Birth Weight, Body Weight, Carcass Weight, Slaughter Age

\section{Introduction}

Dairy breeding programs aim to improve the milk production traits, as these are the main source of income for dairy enterprises. Specialization of farming systems has resulted in most dairy herds becoming purely milk production enterprises in contrast to past systems. Breeding and selection programs towards increased milk yield have resulted in cows showing more dairy character or "sharpness", with cows having a lower beef production potential [1]. Bull calves are produced from dairy enterprises and are ordinarily raised for veal and beef production in most dairy enterprises in South Africa. However, as dairy animals, their beef production characteristics are poor; hence the beef production potential from South African dairy herds is not fully exploited. Bull calves are therefore generally regarded as unwanted animals and are sold at low prices. Given the numbers of bull calves produced in dairy enterprises, significant income can be obtained from bull calves if their beef production traits are improved.

On the other hand, culling of cows not becoming pregnant to maintain a strict seasonal calving system have in some countries such as Ireland resulted in fertile cows requiring low replacement rates to maintain herd sizes. This provides the opportunity to inseminate a considerable portion of the herd with beef semen to increase the beef potential of dairy herds. In South Africa, this practice may not always possible as the internal herd growth of most dairy herds is questionable because of high culling rates of cows and poor success rate of heifer rearing. In the 1980's, a major portion of the beef animals in the United Kingdom was born in dairy herds and was reared for beef production. Variations exist in the beef production potential of different dairy breeds, which creates differences in the need to improve beef traits between breeds. For instance, Kempster et al., [2] reported that Canadian Holsteins slaughtered either at 16 or 24 months of age, had a lower carcass weight and conformation score in comparison to British Friesian steers.

The Jersey breed is one the major dairy breeds used in the South African dairy production systems. It is wellknown for low maintenance requirements, superior grazing ability, less dystocia, high butterfat, docility and high fertility. These characteristics make the Jersey one of the preferred dairy breeds in the country, which is however also known for its poor beef production potential. Even though the tenderness and meat: bone ratio of Jersey steers is high [3], their growth rate is low in comparison to other dairy breeds [4] [5]. Thus, the growth in the Jersey breed replacing Friesian or Holstein herds has further reduced the beef potential of the dairy industry. Breeding programs can be designed to improve beef production characteristics of dairy bull calves. Crossbreeding has become a system to overcome some breeding problems like fertility and longevity in some dairy breeds [6]. Little attention has been given towards using dual-purpose breeds in crossbreeding programmes which provide the opportunity to maintain the milk yield of cows while increasing the beef production of crossbred animals. One such breed to consider is the Fleckvieh, a Simmental-derived breed from Germany. This is a dual-purpose breed with medium to high (in comparison to Holstein cows) milk yield levels and milk components with a high beef production potential. The objective of the study was to compare beef production of Jersey and Fleckvieh $\times$ Jersey $(\mathrm{F} \times \mathrm{J})$ bull calves and steers reared intensively for veal and for beef in a partly pasture-based feeding system.

\section{Materials and Methods}

\subsection{Site Description}

The study was conducted at the Elsenburg Research Farm of the Western Cape Department of Agriculture. Elsenburg is situated approximately $50 \mathrm{~km}$ east of Cape Town at an altitude of $177 \mathrm{~m}$, longitude $18^{\circ} 50^{\prime}$ and latitude $33^{\circ} 51^{\prime}$ in the winter rainfall region of South Africa. The area has a typical Mediterranean climate with short, cool, wet winters and long, warm, dry summers with an average annual rainfall of $650 \mathrm{~mm}$. 


\subsection{Study Design}

Beef production data were collected over four years between 2007 and 2010. A total of 22 pure Jersey bull calves and 39 Fleckvieh $\times$ Jersey $(\mathrm{F} \times \mathrm{J})$ bull calves were used as experimental animals for veal production. For steer production, 22 Jersey steers and $23 \mathrm{~F} \times \mathrm{J}$ steers were used as experimental animals. All crossbred calves and steers ranging from $25 \%$ to $75 \%$ Fleckvieh were included in the study. They were all considered collectively as $\mathrm{F} \times \mathrm{J}$ regardless of the sire used to reach these percentages. All calves were reared equally and marketed as veal at approximately 6 months of age and as beef at 21 months of age. Bull calves reared for beef were castrated at three months of age with a Burdizzo and steer calves were dehorned at two months of age.

For the veal production system, calves were fed intensively using a commercial calf starter meal to 2 months of age and a calf growth meal to marketing, viz. a carcass weight not exceeding $100 \mathrm{~kg}$. For the beef production system, Jersey and $\mathrm{F} \times \mathrm{J}$ bull calves were reared similarly as the veal production system to 3 months of age, after which they were put on kikuyu pasture supplemented with about $2 \mathrm{~kg}$ of a calf growth meal to 6 months of age. After 6 months, they were kept on natural pasture, i.e. pasture was rain-fed and no fertilizers were used. During summer droughts, pasture was supplemented with oats hay. Fresh drinking water was freely available at all times.

\subsection{Data Collection and Statistical Analysis}

Birth weights were recorded when bull calves were removed from their dams to be put into individual crates at two days of age. Thereafter, calves were weighed once a month. On reaching a live weight of about $180 \mathrm{~kg}$, the calves reared for veal, and were weighed once a week on a Thursday. When a body weight of approximately 195 $\mathrm{kg}$ was reached, these bull calves were marketed the following Tuesday. The calves were weighed before leaving to the abattoir (end body weight), where hot and cold carcass weights were recorded after slaughter. Bull calves reared for beef were grouped according to calving date which had to be within 7 days of each other for both breeds. This was to ensure that animals from both breeds were exposed to similar environmental conditions over the 21-month growing-out period. Similarly, bull calves were weighed at birth and thereafter, once a month until marketing at 21 months of age when they were transported to the abattoir.

The data were analysed using the PROC GLM procedures of the SAS (2009) to estimate the effects of breed, season and year on birth weight (BW), end body weight (EBW), average daily gain (ADG), carcass weight $(\mathrm{CW})$, dressing percentage and market age on beef production traits. Least square means were calculated for each factor, where they were separated using the PDIFF STDERR of SAS (2009).

The model used was:

$$
Y_{i j k}=\mu+B_{i}+S_{i}+J_{k}+\beta_{0}(S A G E)_{i j k}+e_{i j k}
$$

where: $\boldsymbol{Y}_{\boldsymbol{i j k}}$ is an observation for each trait, $\boldsymbol{\mu}$ is the population mean, $\boldsymbol{B}_{\boldsymbol{i}}$ is the effect of the $i^{\text {th }}$ breed, $\boldsymbol{S}_{\boldsymbol{j}}$ is the effect of the $j^{\text {th }}$ season, $\boldsymbol{J}_{\boldsymbol{k}}$ is the effect of the $k^{\text {th }}$ year, $\boldsymbol{\beta}_{0}$ is the linear regression coefficient of the observed trait on slaughter age; (SAGE) $)_{i j k}$ is the slaughter age, and $\boldsymbol{e}_{i j k}$ is the random error. Slaughter age was included as a linear covariate in the model for end body weight, carcass weight and dressing percentage.

\section{Results}

\subsection{Effect of Breed on Beef Production}

The least square means and standard errors of the effect of breed on beef production of Jersey and $\mathrm{F} \times \mathrm{J}$ veal calves and steers are shown in Table 1 and Table 2. Breed had an effect $(\mathrm{P}<0.001)$ on the growth performance of the Jersey and $\mathrm{F} \times \mathrm{J}$ veal calves and steers. Year and season had no effect on the growth performance of calves and steers. The interactions between season and year did not reach significance and only main effect means were thus presented. The birth weight (BW) of Jersey and $\mathrm{F} \times \mathrm{J}$ bull calves reared for veal differed.

Crossbred bull calves had higher ( $\mathrm{P}<0.001)$ ADG compared to purebred calves. Crossbred bull calves reached the required live weight for veal averaging 32 days earlier $(\mathrm{P}<0.001)$ than Jersey bull calves. The birth weight of Jersey was lower than that for $\mathrm{F} \times \mathrm{J}$ bull calves. Crossbred bull calves had a $37 \%$ higher $(\mathrm{P}<0.001)$ end live weight at 21 months marketing age thanJersey steers. 
Table 1. Effects of breed on growth performance of Jersey $(\mathrm{J})$ and Fleckvieh $\times$ Jersey $(\mathrm{F} \times \mathrm{J})$ veal calves.

\begin{tabular}{ccc}
\hline Variables & Jersey $(\mathrm{J})$ & Fleckvieh $\times$ Jersey $(\mathrm{F} \times \mathrm{J})$ \\
\hline Number of records & 22 & 39 \\
Birth weight $(\mathrm{kg})$ & $27.9^{\mathrm{a}} \pm 1.2$ & $33.5^{\mathrm{b}} \pm 1.2$ \\
BW at 6 m of age $(\mathrm{kg})$ & $163.5^{\mathrm{a}} \pm 3.9$ & $180.6^{\mathrm{b}} \pm 4.0$ \\
ADG (kg/d) & $0.73^{\mathrm{a}} \pm 0.02$ & $0.82^{\mathrm{b}} \pm 0.02$ \\
Hot carcass weight (kg) & $89.0^{\mathrm{a}} \pm 1.9$ & $94.2^{\mathrm{a}} \pm 1.7$ \\
Cold carcass weight (kg) & $86.2^{\mathrm{a}} \pm 1.9$ & $89.5^{\mathrm{a}} \pm 1.7$ \\
Dressing (\%) & $0.47^{\mathrm{a}} \pm 0.01$ & $0.50^{\mathrm{b}} \pm 0.01$ \\
Market age (m) & $7.1^{\mathrm{b}} \pm 0.1$ & $6.3^{\mathrm{a}} \pm 0.1$ \\
\hline
\end{tabular}

${ }^{\mathrm{a}, \mathrm{b}}$ Means within the same row with different superscripts are significantly different $(\mathrm{P}<0.01)(\mathrm{BW}=$ body weight, $\mathrm{ADG}=$ average daily gain).

Table 2. Effects of breed on growth performance of Jersey $(\mathrm{J})$ and Fleckvieh $\times$ Jersey $(\mathrm{F} \times \mathrm{J})$ steers.

\begin{tabular}{ccc}
\hline Variables & Jersey $(\mathrm{J})$ & Fleckvieh $\times$ Jersey $(\mathrm{F} \times \mathrm{J})$ \\
\hline Number of records & 22 & 23 \\
Birth weight (kg) & $26.9^{\mathrm{a}} \pm 0.9$ & $33.4^{\mathrm{b}} \pm 0.9$ \\
LW at 21 m of age (kg) & $322.6^{\mathrm{a}} \pm 13.4$ & $441.4^{\mathrm{b}} \pm 14.9$ \\
ADG (kg/d) & $0.46^{\mathrm{a}} \pm 0.02$ & $0.64^{\mathrm{b}} \pm 0.02$ \\
Hot carcass weight (kg) & $162.5^{\mathrm{a}} \pm 8.7$ & $212.1^{\mathrm{b}} \pm 9.1$ \\
Cold carcass weight (kg) & $157.9^{\mathrm{a}} \pm 8.6$ & $206.5^{\mathrm{b}} \pm 8.9$ \\
Dressing (\%) & $0.49^{\mathrm{a}} \pm 0.01$ & $0.47^{\mathrm{a}} \pm 0.01$ \\
\hline
\end{tabular}

${ }_{a, b}$ Means within the same row with different superscripts are significantly different $(\mathrm{P}<0.01)(\mathrm{LW}=$ Live weight, ADG = average daily gain).

\subsection{Effect of Season and Year on Beef Production}

The least square means and standard errors of the effect of year on beef production of Jersey and $\mathrm{F} \times \mathrm{J}$ veal calves are shown in Table 3 . The interactions between season and year did not reach significance between breeds. The effect of season on both veal and steer production systems for Jersey and $\mathrm{F} \times \mathrm{J}$ calves did not have an effect $(\mathrm{P}>0.05)$ on all growth traits. The effect of year on steer production system did not yield any significance for both breeds. The effect of year affected $(\mathrm{P}<0.05)$ birth weight, end body weight, ADG and carcass weight of only $\mathrm{F} \times \mathrm{J}$ calves for veal production system. The traits measured were significantly lower during the first two earlier years of the trail.

\section{Discussion}

In the present study, crossbred bull calves were observed to have higher birth weight than Jersey bull calves which could be attributed to their reported higher average daily gain compared to Jersey bull calves. Differences between bull calves were in agreement with [7] and [8] although studies were at the preliminary stages. Crossbreds also reached the required live weight for veal one month earlier than Jersey bulls. Naude \& Armstrong [9] also found low growth rates and efficiency of gain for purebred Jersey steers in comparison to beef-Jersey crossbred steers, and the weight gain of Jersey bulls was improved by $39 \%$ from crossbreeding with Simmental bulls. Jersey steers grew slowly and when slaughtered at 22 - 23 months of age, their carcass were too light [10].

Reported heavier carcass weight for beef crosses in this study were consistent with the study by [11] who found carcass weight of Jersey to be lower than that of crossbreds on beef production of Belgian-Blue/Jersey, Limousin/Jersey and Jersey cattle in a pasture-based system. Beef breeds $\times$ Holstein-Friesians have been reported to have superior carcass weight and conformation compared to pure Holstein-Frisians dairy breed [12][15]. Crossbred calves of Jersey cows sired with Belgian-Blue and Limousin bulls were also reported to be heavier at birth than Jersey calves, i.e. 32 and 31 vs. 24 kg, respectively [11]. Purchas et al, [16] and [10] also found that the disadvantages of purebred Jersey cattle in beef production were greatly reduced by crossbreeding with beef breeds. Breed cross effect became more evident and the live weight advantage continued through to 
Table 3. Effects of breed on growth performance of Jersey $(\mathrm{J})$ and Fleckvieh $\times$ Jersey $(\mathrm{F} \times \mathrm{J})$ steers.

\begin{tabular}{|c|c|c|c|c|c|}
\hline \multirow[t]{2}{*}{ Variables } & \multirow[t]{2}{*}{ Breed } & \multicolumn{4}{|c|}{ Year } \\
\hline & & 2007 & 2008 & 2009 & 2010 \\
\hline \multirow[t]{2}{*}{ Birth weight (kg) } & Jersey & $27.8^{\mathrm{a}} \pm 4.3$ & $26.4^{\mathrm{a}} \pm 1.9$ & $26.9^{\mathrm{a}} \pm 2.5$ & $29.5^{\mathrm{a}} \pm 2.6$ \\
\hline & $\mathrm{F} \times \mathrm{J}$ & $34.9^{\mathrm{b}} \pm 3.2$ & $37.8^{\mathrm{b}} \pm 2.3$ & $30.9^{\mathrm{a}} \pm 1.1$ & $34.8^{\mathrm{b}} \pm 1.6$ \\
\hline \multirow[t]{2}{*}{ End BW (kg) } & Jersey & $155.5^{\mathrm{a}} \pm 7.3$ & $168.5^{\mathrm{a}} \pm 3.4$ & $166.0^{\mathrm{a}} \pm 4.3$ & $159.9^{\mathrm{a}} \pm 4.5$ \\
\hline & $\mathrm{F} \times \mathrm{J}$ & $152.4^{\mathrm{a}} \pm 12.8$ & $175.3^{\mathrm{a}} \pm 10.0$ & $191.2^{\mathrm{b}} \pm 4.6$ & $191.9^{\mathrm{b}} \pm 6.5$ \\
\hline \multirow[t]{2}{*}{ ADG (kg/d) } & Jersey & $0.70^{\mathrm{a}} \pm 0.04$ & $0.77^{\mathrm{a}} \pm 0.01$ & $0.76^{\mathrm{a}} \pm 0.02$ & $0.71^{\mathrm{a}} \pm 0.02$ \\
\hline & $\mathrm{F} \times \mathrm{J}$ & $0.66^{\mathrm{a}} \pm 0.06$ & $0.79^{\mathrm{b}} \pm 0.05$ & $0.87^{\mathrm{b}} \pm 0.02$ & $0.88^{\mathrm{b}} \pm 0.03$ \\
\hline \multirow[t]{2}{*}{ Hot carcass weight (kg) } & Jersey & $78.3^{\mathrm{a}} \pm 5.9$ & $94.6^{\mathrm{a}} \pm 2.6$ & $94.0^{\mathrm{a}} \pm 3.3$ & $95.0^{\mathrm{a}} \pm 3.6$ \\
\hline & $\mathrm{F} \times \mathrm{J}$ & $75.7^{\mathrm{a}} \pm 4.8$ & $99.3^{\mathrm{b}} \pm 3.5$ & $99.0^{\mathrm{b}} \pm 1.7$ & $99.3^{\mathrm{b}} \pm 2.4$ \\
\hline \multirow[t]{2}{*}{ Cold carcass weight (kg) } & Jersey & $70.0^{\mathrm{a}} \pm 4.9$ & $93.9^{\mathrm{b}} \pm 2.1$ & $90.8^{\mathrm{b}} \pm 2.7$ & $93.0^{\mathrm{b}} \pm 2.9$ \\
\hline & $\mathrm{F} \times \mathrm{J}$ & $68.8^{\mathrm{a}} \pm 5.0$ & $97.1^{b} \pm 3.7$ & $95.7^{\mathrm{b}} \pm 1.8$ & $95.3^{\mathrm{b}} \pm 2.5$ \\
\hline \multirow[t]{2}{*}{ Dressing percentage } & Jersey & $0.45^{\mathrm{a}} \pm 0.2$ & $0.48^{\mathrm{a}} \pm 0.01$ & $0.48^{\mathrm{a}} \pm 0.01$ & $0.49^{\mathrm{a}} \pm 0.01$ \\
\hline & $\mathrm{F} \times \mathrm{J}$ & $0.48^{\mathrm{a}} \pm 0.01$ & $0.50^{\mathrm{a}} \pm 0.01$ & $0.51^{\mathrm{a}} \pm 0.01$ & $0.51^{\mathrm{a}} \pm 0.01$ \\
\hline
\end{tabular}

${ }^{\mathrm{a}, \mathrm{b}}$ Means within the same row with different superscripts are significantly different $(\mathrm{P}<0.01)(\mathrm{BW}=$ body weight, ADG $=$ average daily gain).

slaughter with crosses being significantly heavier at birth, weaning and at the final weighing prior to slaughter [17].

Veal calves were not subjected to pasture grazing and hence there were no season effects. Calves reared for steers to 21 months of age were adequately supplemented with oat hay during summer droughts; thus negating the effect of season. The effect of year on steer production system only affected birth weight, end body weight, ADG and carcass weight of crossbreds during the first two earlier years of the trail, thus this could have been due to feed management errors as the project was still on the initial phase. Most of the related studies that were reviewed made no reference on the effect of season and year on both veal and steer production.

\section{Conclusion}

Breed comparison was conducted using production systems generally used by dairy farmers. Higher growth rates for $\mathrm{F} \times \mathrm{J}$ in comparison to purebred Jersey bull calves reared for either veal or beef production under similar feeding conditions were observed. Crossbred bull calves reached the required body weight for veal, on average 32 days earlier than Jersey bull calves. The end body weight of the $\mathrm{F} \times \mathrm{J}$ steers reared as beef in a pasturebased system was 37\% higher than that of Jersey steers. Although a higher beef production was realized from crossbreeding using a dual-purpose breed, the improvement in milk yield, milk composition and fitness traits would determine the economic value of crossbreeding. Further studies should be conducted to determine the effect of including better quality pasture into the diet of steers reared for beef as only poor quality pasture was available in the present study. This should include the effect of using supplementary feeds to increase the performance of crossbred steers, as steers finished on grass could result in very lean carcasses.

\section{Acknowledgements}

The Eastern Cape Department of Rural Development and Agrarian Reform is acknowledged for funding this study and Elsenburg Research Institute for kind permission to use their data.

\section{References}

[1] Hansen, L.B. (2003) Is Genetics a Cure for Reproductive Loss? 2nd Edition, University of Minnesota, Minneapolis, 48-59.

[2] Kempster, A.J., Cook, G.L. and Southgate, J.R. (1988) Evaluation of British Friesian, Canadian Holstein and Beef Breed $\times$ British Friesian Steers Slaughtered over a Commercial Range of Fatness from 16-Month and 24-Month Beef Production Systems. Animal Production, 46, 365-378. http://dx.doi.org/10.1017/S0003356100018973 
[3] Purchas, R.W., Fisher, A.V., Price, M.A. and Berg, R.T. (2002) Relationships between Beef Carcass Shape and Muscle to Bone Ratio.Meat Science, 61, 329-337. http://dx.doi.org/10.1016/S0309-1740(01)00201-7

[4] Morgan, J.H.L., Pickering, F.S. and Everitt, G.C. (1969) Proceedings of New Zealand Society of Animal Production, 29, 164.

[5] McIvor, S. (2004) Dairy Exporter, 79, 109.

[6] Funk, D.A. (2006) Major Advances in Globalization and Consolidation of the Artificial Insemination Industry. Journal of Dairy Science, 89, 1362-1368. http://dx.doi.org/10.3168/jds.S0022-0302(06)72203-2

[7] Muller, C.J.C. (2006) Preliminary Results on the Growth Performance of Holstein and Fleckvieh-Holstein Bull and Heifer Calves. Fleckvieh World, 2006, 22-24.

[8] Muller, C.J.C. and Botha, J.A. (2008) Preliminary Results on Crossbreeding Jersey with Fleckvieh Sires. Fleckvieh World, 2008, 7-9.

[9] Naude, R.T. and Armstrong, C.W.B. (1967) Beef Production from Jersey and Crossbred Steers and Bulls. Proceedings of South African Society Animal Production, 1967, 156-161.

[10] Barton, A.R., Donaldson, J.L., Barnes, F.R., Jones, C.F. and Clifford, H.J. (1994) Comparison of Friesian, FriesianJersey Cross, and Jersey Steers in Beef production. New Zealand Journal of Agricultural Research, 37, 51-58. http://dx.doi.org/10.1080/00288233.1994.9513040

[11] Muller, C.J.C., Meeske, R., van der Merwe, G.D. and Botha, J.A. (2004) Preliminary Results on the Beef Production of Belgian-Blue $\times$ Jersey, Limousin $\times$ Jersey, and Jersey Cattle in a Pasture-Based System. South African Animal Science, 5, 18-20.

[12] Everitt, G.C., Jury, K.E., Dalton, D.C. and Langridge, M. (1980) Growth and Carcass Composition of Straight-Bred and Beef-Cross Friesian Steers in Several Environments. New Zealand Journal of Agricultural Research, 23, 11-20. http://dx.doi.org/10.1080/00288233.1980.10417840

[13] Keane, M.G. and Allen, P. (2002) A Comparison of Friesian-Holstein, Piemontese $\times$ Friesian-Holstein and Romagnola $\times$ Friesian-Holstein Steers for Beef Production and Carcass Traits. Livestock Production Science, 78, 143-158. http://dx.doi.org/10.1016/S0301-6226(02)00086-6

[14] Keane, M.G. (2003) Beef Production from Holstein-Friesian Bulls and Steers of New Zealand and European/American descent, and Belgian Blue $\times$ Holstein-Friesians, Slaughtered at Two Weights. Livestock Production Science, 84, 207218. http://dx.doi.org/10.1016/S0301-6226(03)00092-7

[15] Keane, M.G. (2011) Beef Cross Breeding of Dairy and Beef Cows. Grange Beef Research Centre, Occasional Series No. 8.

[16] Purchas, R.W., Barton, R.A. and Hunt, I.R. (1992) Growth and Carcass Characteristics of Crossbred Steers out of Jersey Cows. New Zealand Journal of Agricultural Research, 35, 393-399. http://dx.doi.org/10.1080/00288233.1992.10421347

[17] Burke, J.L., Purchas, R.W. and Morris, S.T. (1998) A Comparison of Growth, Carcass, and Meat Characteristics of Jersey and Frisian Cross Heifers in a Once-Bred Heifer System of Beef Production. New Zealand Journal of Agricultural Research, 41, 91-99. http://dx.doi.org/10.1080/00288233.1998.9513291

\section{Submit or recommend next manuscript to SCIRP and we will provide best service for you:}

Accepting pre-submission inquiries through Email, Facebook, Linkedin, Twitter, etc

A wide selection of journals (inclusive of 9 subjects, more than 200 journals)

Providing a 24-hour high-quality service

User-friendly online submission system

Fair and swift peer-review system

Efficient typesetting and proofreading procedure

Display of the result of downloads and visits, as well as the number of cited articles

Maximum dissemination of your research work

Submit your manuscript at: http://papersubmission.scirp.org/ 